\title{
Obituaries
}

\section{Dr Geoffrey Pollitt}

\section{Formerly Principal Medical Officer, HM Prison, Wakefield, Yorkshire}

Geoffrey Pollitt was born on 31 October 1920 in Glasgow, where his father ran a long-established paper business. He was educated at St Bees School, in Cumbria, between 1934 and 1938, and then at Queen's College, Cambridge, where he qualified MRCS Eng and LRCP Lond in 1945. The statutory pre-registration period was served as house physician at Herefordshire General Hospital.

After the Second World War, he joined the Royal Navy and served as Senior Medical Officer in HMS Concord during which time he saw action in the Korean War. But it was in 1961, then as promoted Surgeon Commander, that he was posted to Malta and first became involved in psychiatric practice: he set up one of the first specialist units in the Royal Navy to improve psychiatric care.

However, it was on return to 'civvy street' that he decided that psychiatry would be his life's work. He joined the prison service in 1965 and served with distinction until 1990, having gained experience in many of the major prisons, Brixton, Durham, Wakefield and Armley, for example.
His academic qualifications relative to psychiatry were: DPM 1958, DMJ 1966, MRCPsych 1971 and FRCPsych 1979.

Among fellow psychiatrists, Geoffrey Pollitt will always be remembered for his specialised knowledge of the psychopathology of arsonists. His fame for this subject resulted in frequent appearances as expert witness for the Crown in cases of arson, as well as a popular lecturer to learned societies.

After his retirement, he took on a second life as partner in a 100-acre dairy farm in the Yorkshire Dales together with his first wife, Judith Ann, who was the mother of their three sons: Michael, Robin and Simon. Geoffrey and Judith Ann were divorced, leading to the sale of their joint farm. As his second wife Geoffrey married Jill, who predeceased him in 2003.

As yet a third string to his bow, Geoffrey served as chairman of the Menwith-with-Darley parish council, in Nidderdale, for 7 years.

Geoffrey Pollitt died peacefully at his Norfolk home on 1 May 2009, aged 88, leaving behind him his three sons and a host of friends and colleagues.

Michael Pollitt

doi: $10.1192 /$ pb.bp.109.029033

\section{Professor Myre Sim}

\section{Formerly Professor of Psychiatry at the University of Ottawa, Canada}

Professor Sim was born in Scotland on 2 October 1914. He completed his medical and psychiatric training at the University of Edinburgh and was later appointed Professor of Psychiatry at the University of Birmingham. In 1971, he was a founding member of the Royal College of Psychiatrists. He was also elected a Fellow of the American Psychiatric Association. In 1975, he emigrated to Canada, to take up the position of Professor of Psychiatry at the University of Ottawa. Some years later, he and his wife moved to Victoria, British Columbia, where he worked as a consultant psychiatrist.

Myre Sim was a renowned author and contributor to medical agencies and journals. His textbook, Basic Psychiatry, was a popular publication for medical students and graduates alike. He was a consultant to numerous prestigious agencies, including the World Health Organization, and he was involved in publishing pamphlets on various psychiatric topics up to a few months before his passing.

Myre Sim had strong opinions regarding the major ethical problems facing psychiatry today and such opinions tend to foster both vocal advocates and adversaries. As is typical of the medical profession, the old adage, De mortuis nil nisi bonum, will hopefully be honoured at this time.

Professor Sim was predeceased by his wife many years ago and he did not have any children. He remained quite active until he suffered a fractured hip a month before his death on 22 August 2009.

Myre Sim was a most entertaining dinner companion, and knowledgeable on every subject. He was very proud of his Scottish heritage and he had a special regard for Robert Burns, whom he could quote at length.

In the Gaelic tongue, we bid you farewell, for we shall not see your like again!

Slán agus Beannacht (Goodbye and God Bless).

Patrick Perry Lydon

doi: 10.1192/pb.bp.109.029041 